\title{
Health implications of heavy metals in soil, scalp hair and selected food crops within Eldoret Municipality, Kenya
}

\author{
Veronica Ngure ${ }^{1 *}$ Noah Sitati $^{2}$, Silvanus Shisia ${ }^{3}$, Gelas Simiyu ${ }^{4}$, \\ Geoffrey Kinuthia, ${ }^{5}$ and Festus Kelonye ${ }^{6}$ \\ ${ }^{I}$ Department of Biological Sciences, Laikipia University, Kenya \\ ${ }^{2}$ Department of Tourism, Moi University, Kenya \\ ${ }^{3}$ Department of Chemistry, Laikipia University, Kenya \\ ${ }^{4}$ Department of EBH, Moi University, Kenya \\ ${ }^{5}$ Department of Biological Sciences, Daystar University, Kenya \\ ${ }^{6}$ Department of Chemical Technology, Eldoret Polytechnic. Kenya
}

\begin{abstract}
Heavy metals were analyzed in soils, food crops and male scalp hair samples collected from two age group subjects; adults (18 - 45 years) and old age (46 - 55 years) males from polluted and relatively less polluted areas in Eldoret Municipality environs, Kenya. The samples used were collected from same sites as the individuals who had stayed in the sampled regions for more than five years. The samples were digested using acids and analyzed using Atomic Absorbtion Spectrometry (AAS). The results revealed that the consumption of food crops grown on contaminated soils have significantly increased the concentrations of selected metals in the human hair. Pd and Cd concentrations in soils and food crops showed elevated levels above the WHO recommended limits. $\mathrm{Pb}, \mathrm{Cd}, \mathrm{Cr}, \mathrm{Cu}$, and $\mathrm{Zn}$ concentrations were significantly higher $(p<0.05)$ in male scalp hair samples collected from polluted area as compared to control area. In conclusion, consumers in the study area are exposed to high health risks associated with bioaccumulation of heavy metals through ingestion of heavy metals resulting from contamination of food crops grown in the study area and should be sensitized on the dangers of heavy metals on their health.
\end{abstract}

Key words: bioaccumulation; heavy metals; male scalp hair; food crops

\section{Introduction}

Heavy metals are natural constituents of the earth's crust. Accumulation of heavy metals in top soil may be affected by parent materials and / or anthropogenic sources. Human activities such as irrigation using wastewater, agricultural fertilizers, pesticides, organic manures, disposal of urban, industrial wastes, mining, smelting process, atmospheric pollution resulting from motor vehicles and combustion of fossil fuels, have drastically altered the balance and biogeochemical cycles of some heavy metals. An assessment of heavy metals in the soil, food crops and human hair are of particular importance because heavy metals, which are potentially harmful to human health, persist in soils for a very long time.

Human exposure to metals such as cadmium $(\mathrm{Cd})$, lead $(\mathrm{Pb})$, chromium $(\mathrm{Cr})$, copper $(\mathrm{Cu})$, zinc $(\mathrm{Zn})$, cobalt (Co) and titanium (Ti), are well documented (Dipietro et al., 1989; Nriagu, 1996; Luoma and Rainbow, 2008; Tian et al., 2011). Non-essential metals such as $\mathrm{Pb}, \mathrm{Cd}$ and $\mathrm{Cr}$ can elicit toxic effects even at low exposure doses (Elijah Oyoo-Okoth,et al., 2012). On the other hand, $\mathrm{Cu}$ which is an essential metal and a component of various enzymes, is involved in collagen synthesis and in the normal development of connective tissues, nerves and immune system (Amaral et al., 2008). Also $\mathrm{Zn}$ is essential and is involved in multiple functions such as enzymes structure and activities, protein transport, hormonal functions and specific receptor sites, which are crucial for the well functioning of biological systems (Apostoli, 2002, Oyoo-Okoth et al., 2012). Whether metals are classified as essential or non-essential, they can be toxic at acute high exposure levels (Waalkes, 2003; Cai et al., 2005; Amaral et al., 2008). Moreover, increasing evidence also points to negative health effects from cumulative, lower level of exposures to some metals (Hu, 2002; Quandt et al., 2010). Although children are reported to be more vulnerable to metal exposures, which may lead to several pediatrics effects including neurodevelopment disorders (Elijah Oyoo-Okoth et al., 2012), adults are also equally at high risk of exposure through ingestion of foods (Ngure et al., 2012).

Nearly all food items consumed in the study area are grown locally which may increase the metal transfer from the geologically enriched environment to humans through food transfer mechanism (Oyoo-Okoth et al., 2010). The high concentrations of heavy metals in urban soils become a potential threat to human health and safety because they can also be easily transferred into human bodies from suspended dust and direct contact. This study assessed heavy metal concentration in soils and foods consumed and in male adults scalp hair in the geologically enriched area. Body tissues such as hair have been very useful in biomonitoring human exposure to 
metals (Nowak, 1998; Harkins and Susten, 2003; Pereira et al., 2000; Amaral et al., 2008; Wang et al., 2009; Li et al., 2011). It was hypothesized that the metal concentrations in hair are characteristic signatures for metal intake from the soil and from food consumed.

\section{Study area}

Eldoret town (Fig 1), in Uasin Gishu County lies in the mid west of the Rift Valley in Kenya, is one of the fastest growing towns in Kenya, with large and small industries and an agriculturally rich surrounding. Five sampling zones were identified and were located at an average radius of eight kilometers from the town centre, the furthest point being $13 \mathrm{~km}$ south of the town centre. The study sites were EATEC, Yamumbi, Hawaii, Kahoya and Jua Kali which formed the non industrial and control site (Fig.1). The County has a population of 894,179 (Male $-50 \%$, Female $-50 \%$ ) and a density of 267 people per $\mathrm{Km}^{2}$, with an age distribution: $0-14$ years $(41.5 \%), 15-64$ years $(55.7 \%), 65+(2.9 \%)(\mathrm{KNBS}, 2010)$. The main food crops available include the, selected food crops such as wide variety of vegetables, potatoes and wheat.

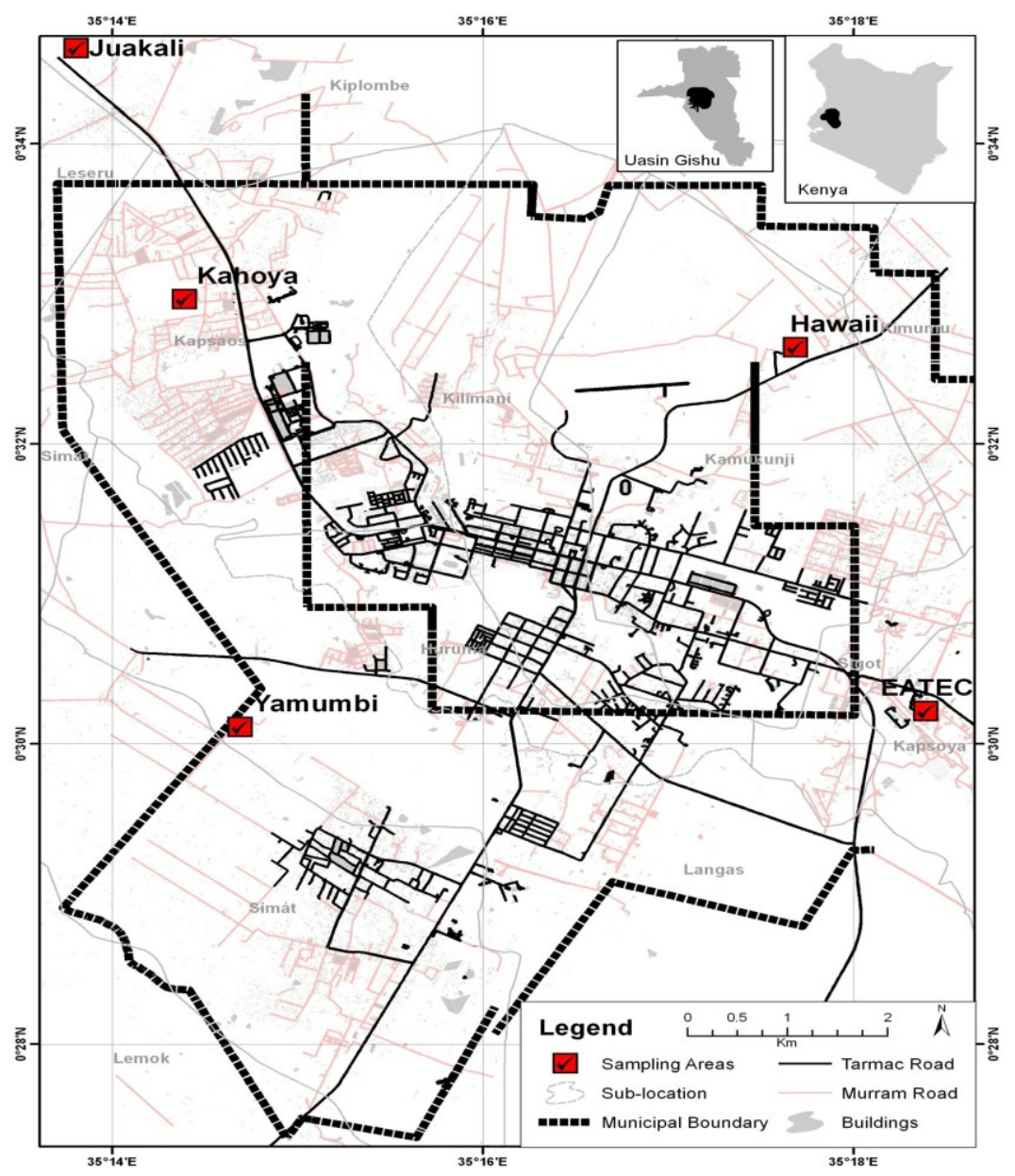

Fig. 1. Map of the Study area and sampling sites

\section{Materials and method}

Heavy metals were analyzed in each of the 150 samples of different soils, food crops and male scalp hair taken during the wet and dry seasons.

\subsection{Sampling and analysis of soil samples}

Soil samples were collected in duplicates from two composite near surface $(10-30 \mathrm{~cm}$ below) from the five sites where a total of 50 samples were collected. Using the assembled sectional auger, 4 holes were made at the corners of the grid of $20 \mathrm{~m}^{2}$ in accordance with IGCP 259 recommendations (Fordyce et al., 2000), from which soil samples were collected using a scoop and homogenized on a plastic sheet. The soil samples were then emptied into air tight plastic containers to retain the moisture content (Fordyce et al., 2000) and taken to the laboratory for metal analyses. The wet season soil samples were oven dried at $32-35^{\circ} \mathrm{C}$ to constant weight for 6 - 
12 hours to avoid loss of metals through volatilization. A sample of $1.250 \mathrm{~g}$ of the soil samples were sieved through $0.002 \mathrm{~mm}$ plastic sieve and transferred to a digestion tube where $50 \mathrm{ml}$ of deionised water was added followed by a mixture of $50 \mathrm{ml}$ conc. $\mathrm{HNO}_{3}$ and $\mathrm{HCl}$ in the ratio of $1: 3$. The contents of the tube were digested at a temperature of $250^{\circ} \mathrm{C}$ for 1 hour, and then raised to $225^{\circ} \mathrm{C}, 250^{\circ} \mathrm{C}$ and $275^{\circ} \mathrm{C}$, respectively at intervals of 15 minutes. After digestion, $5 \mathrm{ml} \mathrm{HNO}$ was added to the mixture and concentrated to $5 \mathrm{ml}$. After cooling, $1 \mathrm{ml}$ of $30 \% \mathrm{H}_{2} \mathrm{O}_{2}$ was added and the mixture heated for 15 minutes. This procedure was repeated once, then $3 \mathrm{ml}$ of $\mathrm{H}_{2} \mathrm{O}_{2}$ was added and the mixture heated for 15 minutes to complete the digestion of organic matter (Fordyce, 2000). Finally, $10 \mathrm{ml}$ of water and $5 \mathrm{ml} \mathrm{HCl}$ were added and the mixture heated to boiling. The mixture was then cooled and transferred to a $50 \mathrm{ml}$ volumetric flask, filled to the mark, and let to settle for at least 15 hours. Flame Atomic Absorption Spectrophotometer analyzed the resultant supernatant for total $\mathrm{Zn}, \mathrm{Pb}, \mathrm{Cu}, \mathrm{Cd}$, and $\mathrm{Cr}$. The total heavy metal contents in soil (ST) were determined in $\mathrm{mg} / \mathrm{kg}$ dry soil from the equation:

$$
\mathrm{ST}=\frac{\mathrm{V}}{\mathbf{1 O O O}} x \frac{C}{\text { Soil mass (g) }} \times 1000 \mathrm{mg} / \mathrm{kg} \text {, Where V is the volume of the digest and } \mathrm{C} \text { the }
$$
concentration in the digest.

\subsection{Sampling and analysis of food crop samples}

A total of 50 food crop samples were collected from the farms in the five zones. Dried food crop samples of maize and selected food crops such as vegetables (kales and peas) and sorghum were washed under tap water, then in distilled water and finally rinsed carefully in deionised water. The samples were weighed to determine the fresh weight and then dried in an oven at $80^{\circ} \mathrm{C}$ for 72 hours to determine the dry weight. The dry samples were crushed in a mortar and the resulting powder sieved through a plastic sieve of $0.002 \mathrm{~mm}$. Approximately $1.250 \mathrm{~g}$ of resultant powder was transferred to a $250 \mathrm{ml}$ conical flask and $25 \mathrm{ml}$ of deionised water and $25 \mathrm{ml}$ of concentrated $\mathrm{HNO}_{3}$ acid were added followed by $30 \% \mathrm{H}_{2} \mathrm{O}_{2}$ to complete the digestion (Fordyce, 2000). Finally, $10 \mathrm{ml}$ of water and $5 \mathrm{ml}$ of $\mathrm{HCl}$ were added and the mixture heated to boiling. The mixture was then cooled and transferred to a $25 \mathrm{ml}$ volumetric flask and let to settle for at least 15 hours. The resultant supernatant was analyzed for heavy metals using Flame Atomic Absorption Spectrophotometer. The total heavy metal contents in maize and were selected food crops determined in $\mathrm{mg} / \mathrm{kg}$ from the equation below:

$$
\mathrm{ST}=\frac{\mathrm{V}}{1000} x \frac{\mathrm{C}}{\text { food crop mass }(\mathrm{g})} \times 1000 \mathrm{mg} / \mathrm{kg}
$$

Where $\mathrm{V}$ is the volume of the digest and $\mathrm{C}$ the concentration in the digest

\subsection{Sampling and analysis of scalp human hair}

The 50 samples of male scalp hair were obtained from residents on the farms where the soil and food crops were collected. Only residents who had lived for five years and were aged between 18-55 years were sampled. Helsinki (1996) protocols, which underline appropriate ethical considerations for studies involving human volunteer participants were followed and permission to carry out this study granted by the Moi University Institute of Research Ethical Committee (IREC). The procedure was first explained to them and those who were willing signed the consent form before donating their hair samples. The assumption was that the respondents sampled had consumed the food crops grown on the soils within the sampling site. Immigrants, sick people and people with colored or treated hair were purposely excluded from the study cohort. Approximately $20 \mathrm{mg}$ of hair samples were collected from the back of the head close to the neck from at least three people in homesteads in the study area. Human hair samples were washed twice in de-ionized water and dried on a clean paper. The dry hair was cut into $2-4 \mathrm{~cm}$ lengths and homogenized and then acid digested by $\mathrm{HNO}_{3}-\mathrm{HCIO}_{4}$ mixture prior to analysis for heavy metals following Fordyce (2000) procedure. The total heavy metal contents in the human hair were determined in $\mathrm{mg} / \mathrm{kg}$ from the equation below:

$$
\mathrm{ST}=\frac{\mathrm{V}}{1000} \times \frac{C}{\text { hair mass }(\mathrm{g})} \times 1000 \mathrm{mg} / \mathrm{kg}
$$

where $\mathrm{V}$ is the volume of the digest, while $\mathrm{C}$ the concentration in the digest.

\section{Results}

\subsection{Distribution of metals in the study area during the study period}

Sample analysis for the heavy metals showed the following total concentrations for both dry and wet seasons in the study area. 
Table 1: Total metal concentration in the soil foodcrops and human hair in the study area

\begin{tabular}{|l|l|l|l|l|l|l|l|l|l|l|l|l|l|l|}
\hline \multicolumn{1}{|l|}{ Soil(mg/kg) } & \multicolumn{1}{|l|}{ Food crops(mg//kg) } & \multicolumn{4}{l|}{ Human hair (mg//kg) } \\
\hline $\mathrm{Zn}$ & $\mathrm{Pb}$ & $\mathrm{Cu}$ & $\mathrm{Cr}$ & $\mathrm{Cd}$ & $\mathrm{Zn}$ & $\mathrm{Pb}$ & $\mathrm{Cu}$ & $\mathrm{Cr}$ & $\mathrm{Cd}$ & $\mathrm{Zn}$ & $\mathrm{Pb}$ & $\mathrm{Cu}$ & $\mathrm{Cr}$ & $\mathrm{Cd}$ \\
\hline 1.783 & 0.653 & 0.294 & 0.523 & 0.0312 & 1.87 & 1.551 & 0.211 & 0.0442 & 0.0322 & 1.621 & 0.6324 & 0.0932 & 0.0423 & 0.0292 \\
\hline
\end{tabular}

Statistical analysis (ANOVA) indicated significant $(\mathrm{F}=3.0015, \mathrm{df}=4, \mathrm{P}=0.021)$ spatial variations between the sampled sites ( $\mathrm{Zn}$ : Kahoya, Pb: Yamumbi, Cu: Kahoya, Cr: Juakali and Cd: Yamumbi) as well as seasonal variations between the dry and wet season in $\mathrm{Zn}$ (Kahoya), $\mathrm{Pb}$ (Yamumbi and Kahoya), $\mathrm{Cu}$ (EATEC, and Hawaii), Cr(Juakali and EATEC).

\subsection{Concentration of heavy metals in soils}

Metal concentrations in soils varied between the five sampling sites (Table 2 Appendix 1, Appendix 1). $\mathrm{Zn}$ concentrations varied significantly among sites $(\mathrm{F}=9.828 \mathrm{df}=4, \mathrm{P}<0.001)$. The Duncan Post hoc test of homogeneity showed that $\mathrm{Zn}$ concentration in soil samples from Kahoya was significantly $(\mathrm{P}<0.05)$ different from other sites. Similar trend was discernible in seasonal variations, Zn concentrations in samples from Jua Kali, EATEC, Yamumbi and Hawaii sites varied insignificantly $(\mathrm{P}>0.05)$ between the dry and wet season's soil samples unlike Kahoya site that showed significant $(\mathrm{P}<0.05)$ seasonal variation. Statistical analysis $($ ANOVA) indicated significant $(\mathrm{F}=3.005, \mathrm{df}=4, \mathrm{P}=0.022)$ spatial variations between the sampled sites as a result of Yamumbi (dry season samples) and Kahoya (wet season samples), which had relatively higher soil $\mathrm{Pb}$ concentrations. The two way interactive spatio-temporal variations were also significant $(\mathrm{F}=3.107, \mathrm{df}=9, \mathrm{P}=$ 0.003 ) for the $\mathrm{Pb}$ metal. Significant spatio-temporal variations in concentration of $\mathrm{Pb}$ were recorded in Kahoya and Yamumbi sampling sites. The concentration of $\mathrm{Cu}$ in soils showed significant statistical difference $(\mathrm{F}=$ $6.327, \mathrm{df}=4, \mathrm{P}<0.001$ ) between the five sampling sites in the dry season (Table 1Appendix 2). However, the concentration of $\mathrm{Cu}$ among sampling sites did not vary significantly $(\mathrm{P}>0.05)$ in the wet season $($ Table 1$)$. Concentration of $\mathrm{Cr}$ in soils of Eldoret Municipality exhibited highly statistical significant difference $(\mathrm{F}=$ 26.667, $\mathrm{df}=4, \mathrm{P}<0.001)$ among the sampling sites (Table 1). Jua kali had significantly $(\mathrm{P}<0.05)$ higher $\mathrm{Cr}$ than $\mathrm{Cr}$ concentrations in other stations. Apparently, significant $(\mathrm{P}<0.05)$ differences were recorded within sites in the dry and wet seasons (Table 2 Appendix 1). The interaction in concentration of $\mathrm{Cr}$ between site and season was significant $(\mathrm{F}=12.204$, df $=9, \mathrm{P}=0.000)$. Significant spatio- seasonal variations in $\mathrm{Cr}$ were displayed in Jua kali and EATEC. Analysis of variance (ANOVA) indicated that concentration of Cd in soils varied significantly among the sampled sites $(\mathrm{F}=31.276, \mathrm{df}=4, \mathrm{P}<0.001)$ (Table 2, Appendix 1). Duncan Post hoc test of homogeneity confirmed high levels of $\mathrm{Cd}$ in Yamumbi. Otherwise other sites that had relatively low levels of $\mathrm{Cd}$ were all statistically similar $(\mathrm{P}>0.05)$. Seasonal variability was also insignificant $(\mathrm{P}>0.05)$ except for Yamumbi which was significant $(\mathrm{P}<0.05)$. Significant spatio-seasonal variations in the concentration of $\mathrm{Cd}$ was noted in Yamumbi.

\subsection{Spatial and seasonal in concentration of metals in maize and selected food crops}

Concentration of metals in food crops was in the order $\mathrm{Zn}>\mathrm{Pb}>\mathrm{Cu}>\mathrm{Cr}>\mathrm{Cd}$. However, the concentrations of $\mathrm{Zn}$ did not exhibit any significant difference $(\mathrm{F}=1.382, \mathrm{df}=4, \mathrm{P}=0.255)$ between the sampling sites (Table 3 Appendix 2). Jua Kali which was the control site had the highest $\mathrm{Zn}$ concentration in food crops $(<3.0 \mathrm{mg} / \mathrm{kg})$. Seasonal variability was also insignificant $(\mathrm{P}>0.05)$ except Kahoya which had significant $(\mathrm{P}<0.05)$ seasonal variability. Significant spatio-seasonal variations in the concentration of $\mathrm{Zn}$ was in Kahoya. Significantly $(\mathrm{P}<0.05)$ high concentration of $\mathrm{Pb}$ was recorded in Jua Kali and Yamumbi in comparison to other sampling sites with a concentration of $<2.0 \mathrm{mg} / \mathrm{kg}$. Moderate concentrations of $\mathrm{Pb}$ were obtained in food crops from EATEC and Hawaii while concentration of $\mathrm{Pb}$ in Kahoya was the lowest. Hence this shows that seasonal variability was insignificant $(\mathrm{P}>0.05)$ except in Yamumbi and Kahoya which exhibited significant $(\mathrm{P}<0.05)$ seasonal variability. Significant spatio-seasonal variation in concentration of $\mathrm{Pb}$ was in Yamumbi and Kahoya. Concentration of $\mathrm{Cu}$ in food crops was significantly different $(\mathrm{F}=16.347, \mathrm{df}=4, \mathrm{P}<$ 0.001 ) among the five sampling sites. The concentration of $\mathrm{Cu}$ in food crops was highest in Jua Kali $(0.250 \mathrm{mg} / \mathrm{kg})$, and significantly higher $(\mathrm{P}<0.05)$ compared to other sites. Equally, $\mathrm{Cu}$ concentration in food crops from EATEC and Yamumbi, was significantly $(\mathrm{P}<0.05)$ higher than from Kahoya. Seasonal variability was also significant $(\mathrm{P}<0.05)$ except Jua Kali and Yamumbi, which exhibited insignificant $(\mathrm{P}>0.05)$ seasonal variation between the wet and dry season samples. Concentration of $\mathrm{Cr}$ in food crops exhibited highly significant difference $(\mathrm{F}=31.963, \mathrm{df}=4, \mathrm{P}<0.001)$ between the sampling sites. The highest concentration of $\mathrm{Cr}$ was recorded in food crops from Jua Kali and Hawaii (Table 3 Appendix 2). Food crops from Kahoya and EATEC had intermediate levels of Cr. However, food crops from Yamumbi had the lowest concentration of Cr. Seasonal variability was also significant $(\mathrm{P}<0.05)$ in Jua Kali and EATEC sites but Yamumbi, Kahoya and Hawaii exhibited insignificant $(\mathrm{P}>0.05)$ seasonal variability. A significant spatio-seasonal variation in concentration of $\mathrm{Cr}$ was observed in Jua Kali (Table 3 Appendix 2). The concentration of Cd in food crops did not show any significant difference between the sampling sites $(\mathrm{F}=2.451$, $\mathrm{df}=4, \mathrm{P}=0.061)$. There was a 
significant $(\mathrm{P}<0.05)$ seasonal variability in Yamumbi while the other sites had insignificant $(\mathrm{P}>0.05)$ seasonal variability (Table 3 Appendix 2). A further, significant spatio-seasonal variation in the concentration of $\mathrm{Cd}$ was in Yamumbi.

\subsection{Spatial and seasonal concentration of metals in human hair}

The concentration of heavy metals in male scalp hair was in the order $\mathrm{Zn}>\mathrm{Pb}>\mathrm{Cu}>\mathrm{Cr}>\mathrm{Cd}$. The concentration of $\mathrm{Zn}$ varied $(\mathrm{F}=31.868$, df $=4, \mathrm{P}<0.001)$ between sampling sites. Hawaii had the highest concentration of $\mathrm{Zn}$ in human hair while intermediate levels were recorded from Jua Kali and Kahoya residents, which were all significantly higher than $\mathrm{Zn}$ obtained in human hair from residents of Yamumbi and EATEC (Table 4 Appendix 3). Seasonal variability was significant $(\mathrm{P}<0.05)$ in Kahoya site while the other sites had insignificant $(\mathrm{P}>0.05)$ seasonal variability. A further, significant spatio-seasonal variation in concentration of $\mathrm{Zn}$ was observed in Kahoya. Non significant $(\mathrm{F}=1.003, \mathrm{df}=4, \mathrm{P}=0.416)$ spatial variation in the concentration of $\mathrm{Pb}$ in human hair was discerned for the residents living in various sampling sites. However, significant $(\mathrm{P}<0.05)$ seasonal variability was observed in Yamumbi and Kahoya (Table 3 Appendix 2). Similarly, significant spatio-seasonal variation in the concentration of $\mathrm{Pb}$ was observed in Yamumbi. The concentration of $\mathrm{Pb}$ among the Eldoret Municipality residents demonstrated significant $(\mathrm{F}=2.792 .879, \mathrm{df}=4, \mathrm{P}=0.037)$ spatial variations among the sampled stations. Significantly $(\mathrm{P}<0.05)$ higher concentrations of $\mathrm{Cu}$ were recorded in male scalp hair in Jua Kali and Kahoya residents than the residents of EATEC, Yamumbi and Hawaii residents. Seasonal variability was significant $(\mathrm{P}<0.05)$ in EATEC, Yamumbi and Hawaii while the other sites had insignificant $(\mathrm{P}>0.05)$ seasonal variability (Table 4 Appendix 3). A further, significant spatio-seasonal variation in concentration of $\mathrm{Cu}$ was observed in Kahoya. The concentration of $\mathrm{Cr}$ exhibited highly significant difference $(\mathrm{F}=66.041, \mathrm{df}=4, \mathrm{P}<0.001)$ among the sampling stations. Significantly higher concentration of $\mathrm{Cr}$ was recorded in human hair from residents living in Jua Kali, EATEC and Yamumbi (Table 3 Appendix 2). However, seasonal variability was significant $(\mathrm{P}<0.05)$ in Jua Kali and EATEC while Yamumbi, Kahoya and Hawaii had insignificant $(\mathrm{P}>0.05)$ seasonal variability. A further, significant spatio-seasonal variation in the concentration of $\mathrm{Cr}$ was observed in Jua Kali only. Finally, the concentration of $\mathrm{Cd}$ in human hair were significantly different among the sampled sites $(\mathrm{F}=4.617, \mathrm{df}=4, \mathrm{P}=0.003)$. However, higher levels of $\mathrm{Cd}$ were found in Kahoya followed by Jua Kali, EATEC and Yamumbi, respectively (Table 3 Appendix 2). Least $\mathrm{Cd}$ concentration occurred in Hawaii. Seasonal variability was significant $(\mathrm{P}<0.05)$ in Yamumbi. However, significant spatio-seasonal variation in the concentration of $\mathrm{Cd}$ was observed in Yamumbi.

\section{Discussion}

Soil is an important component of terrestrial ecosystems owing to the key functions in fertility, decomposition processes, nutrient and energy flows. However, in this study, there is an apparent deterioration of the soil quality due to heavy metal contamination as observed, which may be passed through the food chain and pose a great health risk to the consumers. The concentration of $\mathrm{Cd}$ in soil in all sites was above the reported acceptable concentration of $<0.010 \mathrm{mg} / \mathrm{kg}$ (Frink, 1996). The high levels of $\mathrm{Cd}$ in soils could be attributed to heavy use of phosphate fertilizers and farm manure during farming. Further, the fertilizer inputs, batteries, fungicides, incineration of tyres, rubber, iron roofs and motor oil, which contain $\mathrm{Cd}$, could have elevated the heavy metal in the soils. Equally, the concentration of $\mathrm{Pb}$ in food crops in all sites except Kahoya exceeded recommended level of $<0.2 \mathrm{mg} / \mathrm{kg}$ (CPDM, 1994; CDPM, 1995). Zinc concentration in male scalp hair in Hawaii $(<2.389 \mathrm{mg} / \mathrm{kg})$ was higher than the recommended concentration $(1.357 \mathrm{mg} / \mathrm{kg})$ (Nowak and Chmielnicka, 2000) while hair $\mathrm{Cu}$ in Juakali was above reported levels of polluted cases (Amaral et al., 2008). However, the concentrations of other metals were within the acceptable limits (WHO, 1996) and other internationally accepted standards set by CDPM (1995), and Nowak and Chmielnicka (2000) and Amara et al. (2008). The high concentration of $\mathrm{Zn}$ in soils in Kahoya could be as a result of discharge from industries in the locality, sewerage treatment plant cattle dips, livestock and abattoirs. Equally, the nearby River Sosiani may load $\mathrm{Zn}$ into the soils during flooding. $\mathrm{Pb}$ could be originating from industrial sources such as Corn Product Company, Raiply, and KEN KNIT. Hsu and Lo (2001) established that river systems that have higher metallic loads are likely to increase the amount of heavy metals in their points of deposit and cause massive damage to the environment and may accumulate heavy metals in the soil over time. The concentration of $\mathrm{Zn}$ was higher in food crops than in values reported by Abaja (2002) in Kisumu, but were not higher than the minimum values set by WHO (1996) and CPDM (1995 and 1994). Zn concentration in food crops, did not exhibit any significant difference between the sampling sites, implying lack of accumulation of $\mathrm{Zn}$ as a result of its uptake and elimination by and selected food crops. Equally, leaching of $\mathrm{Zn}$ from the top soils to deeper layers beyond the roots of maize and selected food crops sampled could be another factor. Concentration of $\mathrm{Pb}$ in the food crops showed significantly high spatial variations with high concentrations recorded in Jua Kali and Yamumbi while Kahoya had lower concentrations. Most likely, the physico-chemical characteristics of the soil favoured $\mathrm{Pb}$ uptake by food crops. According to Robertson et al. (1999), several factor interactions increase the 
bioavailability of metals and enhancement of uptake of $\mathrm{Pb}$ by plants. Therefore, the increased levels of $\mathrm{Pb}$ in maize and the selected food crops can be attributed to the ability of maize and selected food crops to bioaccumulate the $\mathrm{Pb}$ and their compounds. Concentrations of $\mathrm{Cu}$ in maize and selected food crops occurred at elevated levels in Jua Kali, attributed to the high levels of $\mathrm{Cu}$ in soils in Jua Kali. The concentrations of $\mathrm{Cr}$ in maize and selected food crops were still higher in Jua Kali and EATEC which is explained by the high Cr levels in the soil. Chromium is normally introduced into food crops via the dissolution of minerals and ores, from industrial effluents, and via atmospheric deposition. Larsen et al. (2005) found elevated concentrations of $\mathrm{Cr}$ and As in soils and plants around a wood preservation factory in Denmark. The slightly higher $\mathrm{Cr}$ concentration in EATEC could be as a result of chromate usage in the processing of tannins. Chromium enters the environment and it is absorbed by food crops. The concentrations of $\mathrm{Zn}$ in human hair were high compared to hair $\mathrm{Zn}(>150$ $\mu \mathrm{g} / \mathrm{g}$ ) observed by Ouyang and $\mathrm{Li}(2000)$, in a comparative study of patients with prostatic carcinoma $(79.9 \pm 37.3 \mu \mathrm{g} / \mathrm{g})$, benign prostatic hypertrophy $(129 \pm 26.7 \mu \mathrm{g} / \mathrm{g})$ and normal controls $(152 \pm 31.5 \mu \mathrm{g} / \mathrm{g})$. Hawaii recorded the highest concentration of $\mathrm{Zn}$ in human hair. However, the area does not have industrial effluent to explain this observation. But it can be explained by poor waste disposal, lack of clean water and people consuming borehole water and due to the presence of small-scale farms. The concentration of $\mathrm{Zn}$ in human blood should be below $5 \mathrm{mg} / \mathrm{l}$ (Alloway, 1990). Nonetheless, the acceptable level of $\mathrm{Zn}$ in humans is quite flexible but more than $2 \mathrm{mg} / \mathrm{l}$ may be undesirable (WHO, 1996). The concentration of $\mathrm{Pb}$ in human hair samples were generally higher compared to a study by Nowak and Chmielnicka (2000). The concentration of $\mathrm{Cu}$ in hair were above $0.01 \mathrm{mg} / \mathrm{kg}$ with elevated levels recorded in Jua Kali followed by Kahoya which could have been obtained through consuming maize and food crops with high concentration of $\mathrm{Cu}$. Human hair $\mathrm{Cr}$ was highest in Yamumbi. Chromium concentration depends on dissolution of minerals and ores, from industrial effluents and via atmospheric deposition which are then absorbed by maize and other food crops from the soil and eventually passed to humans. Further the presence of tannery processing plants in EATEC could have provided the increased levels of $\mathrm{Cr}$ in maize and other food crops grown in the municipality that could have eventually increased the concentration in human hair. The average concentration of $\mathrm{Cr}$ in the body is $0.03 \mathrm{mg} / \mathrm{kg}$ (Parr, 1983). Several non-communicable diseases and disorders have been reported to have a very strong relationship with heavy metals concentration in the environment. Some of the diseases and disorders include cardiovascular diseases, stroke, cancer and high blood pressure (WHO, 1996). Hence, the presence of high concentrations of heavy metals within Eldoret Municipality is a healthy risk. Lowered $\mathrm{Zn}$ levels and high $\mathrm{Pb}$ creates conditions favourable for the development of cardiovascular and hypertension conditions (Goyer, 2004). According to Popko et al. (2003), $\mathrm{Pb}$ and $\mathrm{Zn}$ concentrations have blood related disorders. But Kilic et al. (2004), reported low levels of $\mathrm{Zn}$ and $\mathrm{Cr}$ in scalp hair in patients with breast cancer. Besides Cd toxicity creating cancer, kidney diseases and liver damage, elevated levels of $\mathrm{Cd}$ have been shown to cause hypertension or high blood pressure (Goyer, 2004). Chromium, an obsolete pesticide formulation has been reported as carcinogenic (ATSDR, 2006). Equally hypertension complication is generally as a result of greater concentration of $\mathrm{Cd}$ or higher ratios of $\mathrm{Cd}$ to $\mathrm{Zn}$ in kidneys compared (Stoecker, 1999). Further, studies in North Wales and Cheshire, showed a positive relationship between the concentration of Zn, Co, and Cr and stomach cancer (Stoecker, 1999). Several metals have beneficial effects on heart disease such as $\mathrm{Mn}, \mathrm{Cr}, \mathrm{V}$ and $\mathrm{Cu}$ which are more highly concentrated in the low-death- rate areas like Northern Georgia suggesting that higher mortality may be facilitated by a deficiency rather than an excess of certain trace metals. According to Ouyang and Li (2000), geochemical metals especially $\mathrm{Cd}$ and $\mathrm{Pb}$ could lead to increased environmental related diseases such as cardio-vascular diseases and cancer.

\section{Conclusion}

Eldoret Municipality has elevated levels of some heavy metals, above the WHO recommended limits which are a healthy risk. These heavy metals are absorbed by food crops which are passed onto humans during ingestion. The results revealed that the consumption of food crops grown on contaminated soils have significantly increased the concentrations of selected metals in the human Hair. The agricultural soils in the study area could be limed to alkaline conditions to reduce $\mathrm{Pb}$ uptake by food crops. There is need for public health officials to monitor food crops in Jua Kali. Environmental Regulations and Standards based on Kenya's National Environmental Management Authority need to be closely followed to minimize health risks that may arise from consuming food crops grown on heavy metal contaminated soils.

\section{Acknowledgement}

Special acknowledgement goes to LVEMP for funding this research, Moi University for provision of the laboratory reagents and equipments for heavy metal extraction and analysis. The entire team in the Biochemical Laboratory of Moi University, School Of Environmental studies for assistance in sample collection, temporary storage, preparation, extraction of the heavy metals and finally sample analysis. 


\section{References}

[1]. Alloway, B.J. Heavy metals in soils. Chromium and Nickel. (Blackie and Sons Ltd. John Wiley and Sons Inc., Glasgow and London, New York, 1990).

[2]. Amaral, A.F.S., Arruda, M., Cabral, S., Rodrigues, A.S., Essential and non-essential trace metals in scalp hair of men chronically exposed to volcanogenic metals in the Azores, Portugal. Environ. Int. 34, 2008, 1104-1108.

[3]. Apostoli, P., Element in environmental and occupational medicine. J. Chro-matogr. B, 998, 2002, 63-97.

[4]. ATSDR (Agency for Toxic Substances and Disease Registry) Public Health Statement. Agency for Toxic Substances and Disease Registry, Division of Toxicology; Atlanta, Georgia, 2006.

[5]. Cai, L., Li, X., Song, Y., Cherian, M.G., (2005). Essentiality, toxicology and chelation therapy of zinc and copper. Curr. Med. Chem. 12, 2005, 2753-2763.

[6]. CDPM, Threshold for food Hygiene. Beijing, China Standard Press. 1994.

[7]. CDPM, Threshold for food Hygiene. Beijing, China Standard Press, 1995.

[8]. Dipietro, E.S., Phillips, D.L., Paschal, D.C., Neese, J.W.. Determination of trace elements, in human hair: reference intervals for 28 elements in nonoccupationally exposed adults in the US and effect of hair treatments. Biol. Trace Elem. Res. 22, 1989, 83-100.

[9]. Fordyce, F. Geochemistry and Health- why geosciences information is necessary. Geoscience and Development. 6: 2000, 6-8.

[10]. Fordyce, F. and Johnson, C. The rock diet. Planet Earth. Natural Environment Research Council. 2002,. Pp18.

[11]. Frink, C.R. (1996). A perspective of metals in soils. Journal of soil Contamination, 5(4): 1996, 329-359.

[12]. Goyer, R., Mari, G., Harlal, C., and Michael, H. Issue paper on the human health effects of metals: Submitted to U.S. Environmental Protection Agency Risk Assessment Forum, 200 Pennsylvania Avenue, NW, Washington, DC 20460, August 2004

[13]. Harkins, D.K., and Susten, A.S. Hair analysis: exploring the state of the science. Environ. Health Perspect. 111, 2003, 576-578.

[14]. Hu, H., Human health and heavy metal exposure. In: McCally, M. (Ed.), Life Support: The Iyengar, V., Woittiez, J., Trace elements in human clinical specimens: evaluation of literature data to identify reference values. Clin. Chem. 34, 1988, 474- 481.

[15]. Hsu, J.H. and Lo, S.L. (2001). Effects of composting on characterization and leaching of copper, manganese and zinc from swine manure. Environmental Pollution. 114: 2001, 119-127.

[16]. Kenya National Bureau Statistics,. KENYA: 2009 Population and Housing Census Highlights. 2010

[17]. Kilic, E., Saraymen, R., Demiroglu, A., and Ok, E. (2004). Chromium and manganese levels in the scalp hair of normal and pati ents with breast cancer. Biological Trace Elements Res. 102 (1-3): 2004, 19-25).

[18]. Li, Y., Yang, L., Wang, W., Li, H., Lv, J., Zou, X.. Trace element concentrations in hair of healthy centenarian. Sci. Total Environ. $409,2011,1385-1390$.

[19]. Luoma, S.M., Rainbow, P.S.. Metal Contamination in Aquatic Environments: Science and Lateral Management. Cambridge University Press, Cambridge. 2008.

[20]. Ngure, Veronica, Simiyu, Gelas, Sitati, Noah, Kinuthia, Geoffrey and Shisia, Silvanus. Monitoring exposure to heavy metals through maize consumption using human hair among male adults in Eldoret Municipality, Kenya. Journal of Technology \& Socio Economic Development Volume 1, No. 1,September 2011 Issue

[21]. Nowak, B. Contents and relationship of elements in human hair for a non-industrialised population in Poland. Sci. Total Environ. $209,1998,59-68$.

[22]. Nowak, B., and Chmielnicka, J. Relationship of lead and cadmium to essential ele-ments in hair, teeth, and nails of environmentally exposed people. Ecotoxicol. Environ. Saf. 46, 2000, 265-274.

[23]. Nriagu, J.O. Toxic metal pollution in Africa. Sci. Total Environ. 121, 1992, 1-37.

[24]. Nriagu, J.O. History of global metal pollution. Science 272, 1996, 223-224.

[25]. Oyoo-Okoth, E., Admiraal, W., Osano, O., Ngure, V., Kraak, M.H.S., Omutange, E.S. Monitoring exposure to heavy metals among children in Lake Victoria, Kenya: environmental and fish matrix. Ecotoxicol. Environ. Saf. 73, 2010, 1797-1803.

[26]. Elijah Oyoo-Okoth, Wim Admiraal, Odipo Osano, Michiel H.S. Kraak, Pamela J.A. Were-Kogo, John Gichuki, Veronica Ngure, Judith Makwali, Caleb Ogwai. Dynamics of metal uptake and depuration in a parasitized cyprinid fish (Rastrineobola argentea. ) Aquatic Toxicology. Aquatic Toxicology 124-125, 2012, 34- 40

[27]. Ouyang, S.Y., and Li, S.L. Investigation of trace elements in hair of patients with prostate carcinoma, benign prostatic hypertrophy and normal controls. Hunan Yi Ke Da Xue Bao. 25(3), 2000, 279-80.

[28]. Parr, R.M. (1983). Heavy metals in Human Milk, International Atomic Energy Agency Bulletin 25, 2: 1983, p9.

[29]. Pereira, R., Ribeiro, R., Gonc, alves, F. Scalp hair analysis as a tool in assess-ing human exposure to heavy metals (S. Domingos mine, Portugal). Sci. Total Environ. 327, 2000, 81-92.

[30]. Popko, J., Hukalowilcz, K., Markiewicz, R., Borawska, M.H. and Szeparowicz, P. Pb, Cd, Cu and Zn concentrations in blood and hair of mothers of children with locomotor system malformations. Polish Journal of Environmental Studies. 12: 2003, 375-80

[31]. Quandt, S.A., Jones, B.T., Talton, J.W., Whalley, L.E., Galvin, L., Vallejos, Q.M., Grzywacz, J.G., Chen, H., Pharr, K.E., Isom, S., Arcury, T.A., Heavy metals exposures among Mexican farm workers in eastern North Carolina. Environ. Res. 110, 2010, 83-88.

[32]. Robertson, W.R., Lutrick, M.C. and Yuan, T.L. Heavy application of liquid-digested sludge on three Ultisols. Effects on soil chemistry. Journal of Environtal Quality. 11:, 1999, 278- 82.

[33]. Stoecker, B.J. Chromium. In: Shils, M, Olson, J.A., Shike, M., Ross, A.C., eds. Nutrition in Health and Disease. 9th ed. Baltimore: Williams and Wilkins; 1999, 277-282.

[34]. Tian, W., Egeland, G.M., Sobol, I., Chan, H.M. Mercury hair concentration and dietary exposure among Inuit preschool children in Nunavut, Canada. Environ. Int. 37, 2011, 42-48.

[35]. US EPA. National recommended water quality criteria: 2002-correction: EPA- 822-R-02-047, Washington, DC, USA. Waalkes, M.P., 2003. Cadmium carcinogenesis. Mutat. Res. 533, 2002, 107-120.

[36]. Waalkes, M.P. Cadmium carcinogenesis. Mutat. Res. 533, 2003, 107-120.

[37]. Wang, T., Fu, J.J., Wang, Y.W., Liao, C.Y., Tao, Y.Q., Jiang, G.B., Use of scalp hair as indicator of human exposure to heavy metals in an electronic waste recycling area. Environ. Pollut. 157, 2009, 2445-2451.

[38]. WHO. Heavy metals in human nutrition and health. WHO, Geneva. 1996 


\section{Appendix 1}

Table 2. Spatial-seasonal variations in metals concentration (mean \pm SE) in the soils within Eldoret Municipality

\begin{tabular}{|c|c|c|c|}
\hline \multirow[t]{2}{*}{ Metals } & \multirow[t]{2}{*}{ Sampling sites } & \multicolumn{2}{|c|}{ Metal concentration $(\mathrm{mg} / \mathrm{kg})$} \\
\hline & & Dry season & Wet season \\
\hline \multirow{5}{*}{ Zinc $(\mathrm{Zn})$} & Juakali & $1.6806 \pm 0.0643^{\mathrm{a}}$ & $1.5986 \pm 0.0607^{\mathrm{a}}$ \\
\hline & EATEC & $1.7390 \pm 0.0526^{\mathrm{a}}$ & $1.5220 \pm 0.0640^{\mathrm{a}}$ \\
\hline & Yamumbi & $1.5165 \pm 0.1169^{\mathrm{a}}$ & $1.4187 \pm 0.1101^{\mathrm{a}}$ \\
\hline & Kahoya & $2.3700 \pm 0.3014^{\mathrm{b}}$ & $1.9758 \pm 0.1982^{\mathrm{a}}$ \\
\hline & Hawaii & $1.6364 \pm 0.0367^{\mathrm{a}}$ & $1.5580 \pm 0.0779^{\mathrm{a}}$ \\
\hline \multirow{5}{*}{ Lead $(\mathrm{Pb})$} & Juakali & $0.6020 \pm 0.0259^{\mathrm{b}}$ & $0.5880 \pm 0.0294^{\mathrm{b}}$ \\
\hline & EATEC & $0.6060 \pm 0.0305^{\mathrm{b}}$ & $0.5880 \pm 0.0299^{b}$ \\
\hline & Yamumbi & $0.6810 \pm 0.0260^{\mathrm{c}}$ & $0.5670 \pm 0.0345^{b}$ \\
\hline & Kahoya & $0.5600 \pm 0.0228^{\mathrm{b}}$ & $0.5100 \pm 0.0315^{\mathrm{a}}$ \\
\hline & Hawaii & $0.6620 \pm 0.0122^{b}$ & $0.5800 \pm 0.0290^{b}$ \\
\hline \multirow{5}{*}{ Copper $(\mathrm{Cu})$} & Juakali & $0.2878 \pm 0.0145^{\mathrm{b}}$ & $0.3148 \pm 0.0120^{\mathrm{b}}$ \\
\hline & EATEC & $0.2540 \pm 0.0192^{\mathrm{a}}$ & $0.3300 \pm 0.0136^{\mathrm{b}}$ \\
\hline & Yamumbi & $0.3492 \pm 0.0091^{\mathrm{b}}$ & $0.3772 \pm 0.0116^{\mathrm{b}}$ \\
\hline & Kahoya & $0.2870 \pm 0.0173^{\mathrm{ab}}$ & $0.3036 \pm 0.0184^{b}$ \\
\hline & Hawaii & $0.2758 \pm 0.0150^{\mathrm{a}}$ & $0.3196 \pm 0.0160^{\mathrm{b}}$ \\
\hline \multirow{5}{*}{ Cromium $(\mathrm{Cr})$} & Juakali & $0.7188 \pm 0.0904^{\mathrm{e}}$ & $0.6464 \pm 0.0246^{\mathrm{d}}$ \\
\hline & EATEC & $0.4126 \pm 0.0406^{\mathrm{b}}$ & $0.3326 \pm 0.0167^{\mathrm{a}}$ \\
\hline & Yamumbi & $0.5543 \pm 0.0294^{\mathrm{c}}$ & $0.5069 \pm 0.0275^{\mathrm{c}}$ \\
\hline & Kahoya & $0.4232 \pm 0.0129^{b}$ & $0.3828 \pm 0.0192^{b}$ \\
\hline & Hawaii & $0.2780 \pm 0.0312^{\mathrm{a}}$ & $0.2550 \pm 0.0128^{\mathrm{a}}$ \\
\hline \multirow{5}{*}{ Cadmium (Cd) } & Juakali & $0.0298 \pm 0.0011^{\mathrm{a}}$ & $0.0248 \pm 0.0009^{\mathrm{a}}$ \\
\hline & EATEC & $0.0272 \pm 0.0017^{\mathrm{a}}$ & $0.0234 \pm 0.0017^{\mathrm{a}}$ \\
\hline & Yamumbi & $0.0385 \pm 0.0026^{\mathrm{c}}$ & $0.0319 \pm 0.0023^{b}$ \\
\hline & Kahoya & $0.0196 \pm 0.0011^{\mathrm{a}}$ & $0.0162 \pm 0.0015^{\mathrm{a}}$ \\
\hline & Hawaii & $0.0298 \pm 0.0014^{\mathrm{a}}$ & $0.0260 \pm 0.0013^{\mathrm{a}}$ \\
\hline
\end{tabular}

Mean $( \pm \mathrm{SE}$ ) values with different superscripts a, b, c and for each metal in dry and wet season was significantly different

within the sites at $\propto=0.05$

\section{Appendix 2}

Table 3 Spatial-temporal variations in metals concentration (mean \pm SE) in the maize and other food crops within Eldoret Municipality

\begin{tabular}{|c|c|c|c|}
\hline \multirow[t]{2}{*}{ Metals } & \multirow[t]{2}{*}{ Sampling sites } & \multicolumn{2}{|c|}{ Metal concentration $(\mathrm{mg} / \mathrm{kg})$} \\
\hline & & Dry season & Wet season \\
\hline \multirow{5}{*}{ Zinc $(\mathrm{Zn})$} & Juakali & $2.6806 \pm 0.0623^{\mathrm{a}}$ & $1.6986 \pm 0.0807^{\mathrm{a}}$ \\
\hline & EATEC & $1.9790 \pm 0.0576^{\mathrm{a}}$ & $1.8220 \pm 0.0574^{\mathrm{a}}$ \\
\hline & Yamumbi & $1.5165 \pm 0.1169^{\mathrm{a}}$ & $1.4187 \pm 0.1101^{\mathrm{a}}$ \\
\hline & Kahoya & $2.6700 \pm 0.3014^{\mathrm{b}}$ & $1.9758 \pm 0.1952^{\mathrm{a}}$ \\
\hline & Hawaii & $1.9364 \pm 0.0367^{\mathrm{a}}$ & $1.7580 \pm 0.0779^{\mathrm{a}}$ \\
\hline \multirow{5}{*}{ Lead $(\mathrm{Pb})$} & Juakali & $1.9020 \pm 0.0159^{\mathrm{b}}$ & $1.7880 \pm 0.0294^{\mathrm{b}}$ \\
\hline & EATEC & $1.6060 \pm 0.0305^{\mathrm{b}}$ & $1.5880 \pm 0.0259^{\mathrm{b}}$ \\
\hline & Yamumbi & $1.9810 \pm 0.0260^{\mathrm{c}}$ & $1.8670 \pm 0.0315^{\mathrm{b}}$ \\
\hline & Kahoya & $0.5600 \pm 0.0228^{b}$ & $0.5100 \pm 0.0311^{\mathrm{a}}$ \\
\hline & Hawaii & $1.6620 \pm 0.0122^{b}$ & $1.5800 \pm 0.0290^{b}$ \\
\hline \multirow{5}{*}{ Copper $(\mathrm{Cu})$} & Juakali & $0.2808 \pm 0.0135^{\mathrm{b}}$ & $0.3148 \pm 0.0119^{\mathrm{b}}$ \\
\hline & EATEC & $0.2540 \pm 0.0192^{\mathrm{a}}$ & $0.3300 \pm 0.0136^{\mathrm{b}}$ \\
\hline & Yamumbi & $0.1492 \pm 0.0091^{\mathrm{b}}$ & $0.2112 \pm 0.0176^{\mathrm{b}}$ \\
\hline & Kahoya & $0.0187 \pm 0.016^{\mathrm{ab}}$ & $0.0236 \pm 0.0124^{\mathrm{b}}$ \\
\hline & Hawaii & $0.2058 \pm 0.0150^{\mathrm{a}}$ & $0.1986 \pm 0.0160^{b}$ \\
\hline \multirow{5}{*}{ Cromium $(\mathrm{Cr})$} & Juakali & $0.0622 \pm 0.0804^{\mathrm{e}}$ & $0.0641 \pm 0.0226^{\mathrm{d}}$ \\
\hline & EATEC & $0.0419 \pm 0.0406^{\mathrm{b}}$ & $0.0332 \pm 0.0165^{\mathrm{a}}$ \\
\hline & Yamumbi & $0.0225 \pm 0.0294^{\mathrm{c}}$ & $0.0506 \pm 0.0275^{\mathrm{c}}$ \\
\hline & Kahoya & $0.0423 \pm 0.0159^{b}$ & $0.0382 \pm 0.0172^{b}$ \\
\hline & Hawaii & $0.0627 \pm 0.0312^{\mathrm{a}}$ & $0.0545 \pm 0.0126^{\mathrm{a}}$ \\
\hline \multirow{5}{*}{ Cadmium $(\mathrm{Cd})$} & Juakali & $0.0498 \pm 0.0011^{\mathrm{a}}$ & $0.0348 \pm 0.0009^{\mathrm{a}}$ \\
\hline & EATEC & $0.0472 \pm 0.0017^{\mathrm{a}}$ & $0.0434 \pm 0.0016^{\mathrm{a}}$ \\
\hline & Yamumbi & $0.0385 \pm 0.0026^{\mathrm{c}}$ & $0.0319 \pm 0.0023^{\mathrm{b}}$ \\
\hline & Kahoya & $0.0496 \pm 0.0011^{\mathrm{a}}$ & $0.0362 \pm 0.0015^{\mathrm{a}}$ \\
\hline & Hawaii & $0.0398 \pm 0.0014^{\mathrm{a}}$ & $0.0321 \pm 0.0011^{\mathrm{a}}$ \\
\hline
\end{tabular}

Mean $( \pm \mathrm{SE}$ ) values with different superscripts for each metal in seasos was significantly different within the sites at $\propto=0.05$ 


\section{Appendix 3}

Table 4 Appendix 3. Spatial-temporal variations in metals concentration (mean \pm SE) in the human hair within Eldoret Municipality

\begin{tabular}{|c|c|c|c|}
\hline \multirow[t]{2}{*}{ Metals } & \multirow[t]{2}{*}{ Sampling sites } & \multicolumn{2}{|l|}{ Human hair (mg/kg) } \\
\hline & & Dry season & Wet season \\
\hline \multirow{5}{*}{ Zinc (Zn) } & Juakali & $1.8686 \pm 0.0639^{\mathrm{a}}$ & $1.7986 \pm 0.0607^{\mathrm{a}}$ \\
\hline & EATEC & $1.2390 \pm 0.0526^{\mathrm{a}}$ & $1.3220 \pm 0.0640^{\mathrm{a}}$ \\
\hline & Yamumbi & $1.5165 \pm 0.1156^{\mathrm{a}}$ & $1.4187 \pm 0.1129^{a}$ \\
\hline & Kahoya & $1.6700 \pm 0.3014^{b}$ & $1.5758 \pm 0.1982^{\mathrm{a}}$ \\
\hline & Hawaii & $2.1364 \pm 0.0367^{\mathrm{a}}$ & $2.3580 \pm 0.0779^{\mathrm{a}}$ \\
\hline \multirow{5}{*}{ Lead $(\mathrm{Pb})$} & Juakali & $0.6102 \pm 0.0259^{b}$ & $0.5980 \pm 0.0204^{\mathrm{b}}$ \\
\hline & EATEC & $0.6060 \pm 0.0305^{\mathrm{b}}$ & $0.5880 \pm 0.0299^{b}$ \\
\hline & Yamumbi & $0.8681 \pm 0.0260^{\mathrm{c}}$ & $0.7670 \pm 0.0305^{\mathrm{b}}$ \\
\hline & Kahoya & $0.6879 \pm 0.0228^{\mathrm{b}}$ & $0.5921 \pm 0.0315^{\mathrm{a}}$ \\
\hline & Hawaii & $0.5620 \pm 0.0122^{b}$ & $0.5800 \pm 0.0290^{\mathrm{b}}$ \\
\hline \multirow{5}{*}{ Copper $(\mathrm{Cu})$} & Juakali & $0.1878 \pm 0.0145^{b}$ & $0.1148 \pm 0.0129^{b}$ \\
\hline & EATEC & $0.0840 \pm 0.0192^{\mathrm{a}}$ & $0.0730 \pm 0.0136^{\mathrm{b}}$ \\
\hline & Yamumbi & $0.0792 \pm 0.0091^{\mathrm{b}}$ & $0.0772 \pm 0.0116^{\mathrm{b}}$ \\
\hline & Kahoya & $0.2497 \pm 0.0173^{\mathrm{ab}}$ & $0.2036 \pm 0.0144^{b}$ \\
\hline & Hawaii & $0.1275 \pm 0.0150^{\mathrm{a}}$ & $0.1196 \pm 0.0164^{b}$ \\
\hline \multirow{5}{*}{ Cromium $(\mathrm{Cr})$} & Juakali & $0.0328 \pm 0.0904^{\mathrm{e}}$ & $0.0264 \pm 0.0206^{\mathrm{d}}$ \\
\hline & EATEC & $0.0412 \pm 0.0421^{\mathrm{b}}$ & $0.4326 \pm 0.0132^{\mathrm{a}}$ \\
\hline & Yamumbi & $0.0543 \pm 0.0204^{\mathrm{c}}$ & $0.0506 \pm 0.0205^{\mathrm{c}}$ \\
\hline & Kahoya & $0.0054 \pm 0.0109^{b}$ & $0.0052 \pm 0.0152^{b}$ \\
\hline & Hawaii & $0.0052 \pm 0.0302^{\mathrm{a}}$ & $0.0055 \pm 0.0122^{\mathrm{a}}$ \\
\hline \multirow{5}{*}{ Cadmium (Cd) } & Juakali & $0.0218 \pm 0.0011^{\mathrm{a}}$ & $0.0212 \pm 0.0009^{\mathrm{a}}$ \\
\hline & EATEC & $0.0256 \pm 0.0017^{\mathrm{a}}$ & $0.0234 \pm 0.0017^{\mathrm{a}}$ \\
\hline & Yamumbi & $0.0265 \pm 0.0026^{\mathrm{c}}$ & $0.0219 \pm 0.0023^{b}$ \\
\hline & Kahoya & $0.0296 \pm 0.0011^{\mathrm{a}}$ & $0.0262 \pm 0.0015^{\mathrm{a}}$ \\
\hline & Hawaii & $0.0194 \pm 0.0014^{\mathrm{a}}$ & $0.0178 \pm 0.0013^{\mathrm{a}}$ \\
\hline
\end{tabular}

Mean $( \pm$ SEM) values with different superscripts for each metal in dry and wet season was significantly different within the sites at $\propto=0.05$ 